\title{
Analysis of fabrics and metal threads from two Andalusian liturgical vestments from the seventeenth and eighteenth centuries: a multitechnical approach
}

\author{
Adrián Durán $^{1, \mathrm{a}}{ }_{\mathbb{D}}$, José Luis Pérez-Rodríguez ${ }^{2}$ \\ ${ }^{1}$ Department of Chemistry, University of Navarre, Irunlarrea 1, 31008 Pamplona, Spain \\ 2 Materials Science Institute of Seville, Americo Vespucio, 49, 41092 Seville, Spain
}

Received: 17 August 2021 / Accepted: 25 November 2021

(C) The Author(s) 2021

\begin{abstract}
This manuscript provided one of the first scientific studies performed on ancient Spanish liturgical vestments by using a multitechnical physicochemical approach. The interlining and lining fabrics were done by cotton and the core of threads by silk. Silver, gold and little amounts of copper were detected. The highest values of gold were found in the metal threads of the cope and the gallon of the chasuble. Two layers were identified: the internal composed by silver and the external by silver and gold. The fibers were proved to be degraded and also the surface of the metal, where scratches and silver-based compounds were detected due to environmental and anthropogenic actions. Indigo was employed as dye in the blue and green fabrics. Wax was detected in the yellow fibers, although other dyes could not be discarded. The materials used in the restoration processes were of minor quality.
\end{abstract}

\section{Introduction}

The liturgical vestments are the pieces that are to be worn by the clergy in the religious catholic ceremonies: celebration of the holy mass, processions, blessings, administration of sacraments, etc. [1, 2].

The origins of the copes were in the vestments that the monastic community wore when they moved between churches or monasteries [3]. From the ninth century, the existence of copes has been registered in church inventories [4, 5]. Afterward, these garments became ennobled [3]. The hood was incorporated to the liturgical vestments (copes and other garments) and by the fifteenth century was substituted by a shield-shaped piece of embroidery fabric, which hung from the shoulder and attached with decorative buttons to the body of the vestment (called capillo) [3-5]. In the Baroque era, the wide orphrey running the whole length of the cope was made of a decorated fabric [4, 5].

The main Eucharistic vestment is named the chasuble that means the tunic that Christ wore before the crucifixion. It has a central opening for the head, and it has no arms or seams [3].

The parish church of Our Lady of Consolation in El Pedroso (70 km away from Seville, in the north of Andalusia) is located in the center of the town. Together with the Christ of the

\footnotetext{
a e-mail: adrianduran@unav.es (corresponding author)
} 
Mercy Hermitage and the Espino Virgin Hermitage is the main religious building in the town $[6,7]$. The Consolation Church was originally a Gothic-Mudejar temple, but only the current Baptismal Chapel remains from this period. In the Renaissance era (sixteenth century), some transformations in the church planning occurred and restoration works were carried out on the roofs. In the eighteenth century, this temple was subjected to numerous interventions due to the partial collapses caused by various earthquakes and the temple was also expanded [7].

Our Lady of Consolation parish has a cope and a chasuble with rich embroideries. Both are the two richest and oldest textile pieces, and their study was the aim of this paper.

This type of cultural heritage artifacts has not been largely studied. Only some papers deal with this subject. Metallic parts of the yarns from an Italian chasuble from the fifteenth century and from Croatian liturgical vestments have been recently studied [8,9]. Natural dyes in yellow, orange, brown and green fibers from Krakow liturgical vestments from the fifteenth to seventeenth centuries were also dealt with [10]. Both metallic and colored yarns were studied in a Portuguese cope from the sixteenth century [5] and from Australian copes, chasubles and miters from the nineteenth-twentieth century [3]. Usually, scanning electron microscopy coupled with energy-dispersive X-ray spectroscopy (SEM-EDX), X-ray fluorescence (XRF), proton-induced X-ray emission (PIXE) and inductively coupled plasma—optical emission spectrometry (ICP-OES) were used for determining the composition of metallic pieces [3, $5,8-10]$. The chromatographic techniques are usually used for the identification of textile dyes [5, 10-12]. In our study, we have prioritized the use of nondestructive analysis, such as micro-Raman spectroscopy, to analyze the fibrous helping to the discrimination of the dyes applied [13].

From the best of our knowledge, this type of garment has not been previously studied in Spain from a scientific point of view. We have employed a multianalytical approach to the best study of this valuable artwork. The use of the techniques usually employed for materials science has provided very valuable results.

\section{Materials and methods}

\subsection{Materials}

Our Lady of Consolation parish has a cope with rich embroidery (wide $300 \mathrm{~cm}$ and high $120 \mathrm{~cm}$ ) (Fig. 1a and b) made in the last quarter of the seventeenth or in the early eighteenth century. The cope was described as fabricated with silk and woven with fine gold threads and golden fringes, and trimmed with golden gallons (wide $2 \mathrm{~cm}$ ). The cope was closed with a named silver cope clasp representing the anagram of the Blessed Virgin Mary. Another shield-shaped embroidery piece named capillo (wide $50 \mathrm{~cm}$ and high $50 \mathrm{~cm}$ ) (Fig. 1c) hung from the shoulder and was connected to the cope with buttons.

Samples of original lining (1), interlining (2), fabrics (3), metal threads (4) and gallons (5) from the cope were collected for analysis when a partial restoration was carried out (Fig. 2a). For the restoration of the cope, samples of new gallons (5), metal threads (4) and lining (1) were used and also studied (Fig. 2b). The metal fringes of the capillo (Fig. 1c) were also studied. The restoration of the cope was carried out in 2020 and consisted in the change of lining, the replacement of the gallons (almost non-existent in some borders), the fixation and consolidation of the fabrics in some zones, and a deep cleaning.

The chasuble is the richest vestment piece in the parish (Fig. 1d and e). It was also dated between the seventeenth and eighteenth centuries. Its dimensions were the following: high 

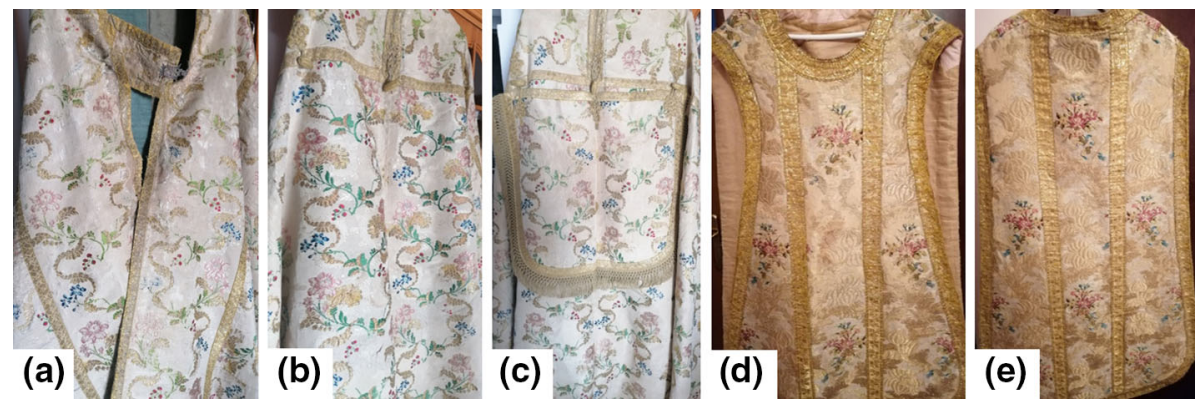

Fig. 1 Photographs corresponding to: (a) cope (front), (b) cope (back), (c) capillo, (d) chasuble (front), (e) chasuble (back)
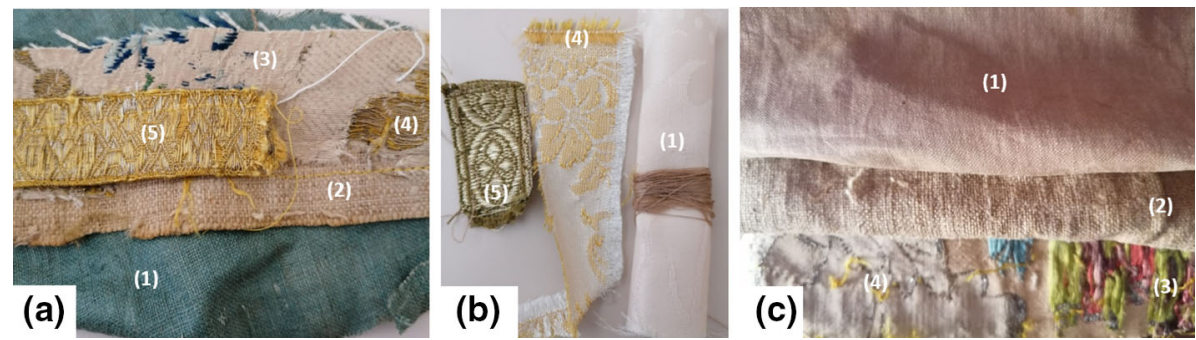

Fig. 2 Stratigraphic distribution of layers forming: (a) cope, (b) restoration materials (new), (c) chasuble [(1) lining, (2) interlining, (3) fabrics, (4) metal thread, (5) gallon]

$110 \mathrm{~cm}$ front and $116 \mathrm{~cm}$ back; wide $65 \mathrm{~cm}$ back — narrowest area — and $41 \mathrm{~cm}$ front — widest area.

In the chasuble, small samples of original lining (1), interlining (2), fabrics (3), metal threads (4) (Fig. 2c) and also gallons were collected. The restoration from 2020 only consisted in the replacement of lining, which was the same one used for the cope.

Both garments were in rather good conditions. The main constraints were found in the lining of both and also in the gallons and the fabrics of the cope because they had disappeared in some areas. In Fig. 2a and c, the different stratigraphic distribution of the components (layers) forming the cope and the chasuble was clearly observed from the inner to surface: lining (1), interlining (2), fabrics (3), metal threads (4) and gallons (5). Both pieces were dated in the same century, but there was no news about the artists who did the artworks.

\subsection{Methods}

To obtain information about the composition of the fabrics and also of dyes, Fourier transform infrared spectroscopy in attenuated total reflectance mode (FTIR-ATR), micro-Raman spectroscopy and thermal analyses (coupled thermogravimetry (TG) and differential thermal analysis (DTA) and also differential scanning calorimetry (DSC)) were the techniques mainly used. In addition, optical (OM) and scanning electron (SEM) microscopy were employed in order to identify the fibers employed.

Regarding the spectroscopic techniques, FTIR-ATR experiments were conducted with a Shimadzu IR Affinity-1S spectrometer with a Golden Gate accessory. The measurements were taken in the range of wavenumbers between 4000 and $600 \mathrm{~cm}^{-1}$. The resolution was 
of $4 \mathrm{~cm}^{-1}$, and 100 scans were chosen for registering the spectra. For Raman acquisitions, the dispersive integrated Horiba Jobin-Yvon LabRaman HR800 apparatus was employed. We primarily used the laser source at $784 \mathrm{~nm}$ (red). The resolution was $2 \mathrm{~cm}^{-1}$, and each spectrum was recorded for 8 to $12 \mathrm{~min}$ in a wavenumber range from 2250 to $200 \mathrm{~cm}^{-1}$.

In the case of the thermal techniques, the simultaneous TG-DTA measurements in a TGA-sDTA 851 Mettler Toledo and also in a TG/DTA/DSC STA449 F5 Jupiter (NETZSCH) instrument device were taken at a linear heating rate of $10^{\circ} \mathrm{C} \cdot \mathrm{min}^{-1}$ over the temperature range from $25^{\circ}$ to $1000{ }^{\circ} \mathrm{C}$ in static air. DTG and TG curves were shown in order to properly distinguish the different thermogravimetric effects produced in both fabrics and metal threads. The DSC experiments were performed with a Universal V4.5A TA Instrument equipment. Four cycles were done from 30 to $80{ }^{\circ} \mathrm{C}$ in heating rate of $5{ }^{\circ} \mathrm{C} \cdot \mathrm{min}^{-1}$.

For SEM experiments, the Hitachi S-4800 microscope was employed using the secondary electron detector. Images of OM were obtained with the PCE-MM200 Digital Microscope.

The metallic threads, fringes and gallons were analyzed using X-ray diffraction (XRD), $\mathrm{X}$-ray fluorescence (XRF), scanning electron microscopy coupled with energy-dispersive of $\mathrm{X}$-rays (SEM-EDX) and optical microscopy (OM).

Concerning X-ray-based techniques, XRD experiments were performed by employing a Bruker D8 Advance diffractometer with a copper anode in the X-rays tube. The $2 \theta$ range covered between 3 and $60^{\circ}$, step size of $0.02^{\circ}$ and $2 \mathrm{~s}$ by step. XRD was employed in order to determine the structural changes and also the presence of solid solutions. The Bruker S2 Puma equipment, with a silver anode and helium atmosphere, was used for XRF analyses.

EDX spectra were obtained with a $25-\mathrm{kV}$ accelerating voltage and at $15-\mathrm{mm}$ working distance with a Bruker Xflash 4010 detector coupled to the Hitachi S-4800 microscope. For quantification purposes, background subtraction and ZAF correction were used.

Also, visual examinations of the garments and the colorimetric evaluation of the original and also of the restoration pieces were performed. The chromatic values $\mathrm{L}^{*} \mathrm{a} \mathrm{b}^{*}$ were obtained by using a normalized D65 light provided by the portable spectrometer CM-2300d Konica Minolta. The average values of the three experiments automatically recorded were provided.

\section{Results}

\subsection{Fabrics}

\subsubsection{Original artifacts}

For the identification of lining, interlining and fabrics in the original artifacts and also in the restoration materials, the techniques employed were mainly infrared spectroscopy with ATR accessory and thermal analysis.

The lining and the interlining of both the cope and the chasuble were made of cellulosic fibers, very possibly cotton (Fig. 3a (1)-(5)). The vibrations at $3334 \mathrm{~cm}^{-1}$ and $3290 \mathrm{~cm}^{-1}$ were assigned, respectively, to intramolecular and intermolecular hydrogen bonding $(\mathrm{OH}-$ stretching) within cellulose [14] and those at 2921 and $2856 \mathrm{~cm}^{-1}$, respectively, to the $\mathrm{CH}_{2}$ asymmetrical and symmetrical stretching vibrations $[14,15]$. The signals at $1640 \mathrm{~cm}^{-1}$ were attributed to $\mathrm{C}=\mathrm{O}$ stretching vibrations from the glycosides [16] and also to adsorbed water [14]. The band at $1429 \mathrm{~cm}^{-1}$ was associated with $\mathrm{CH}_{2}$ scissoring in cellulose [14], and the signals at 1367 and $1318 \mathrm{~cm}^{-1}$ to, respectively, $\mathrm{C}-\mathrm{H}$ bending $[14,16]$ and $\mathrm{C}-\mathrm{O}$ stretching of the aromatic rings of the polysaccharides [16]. The $1028 \mathrm{~cm}^{-1}$ vibration corresponded to 

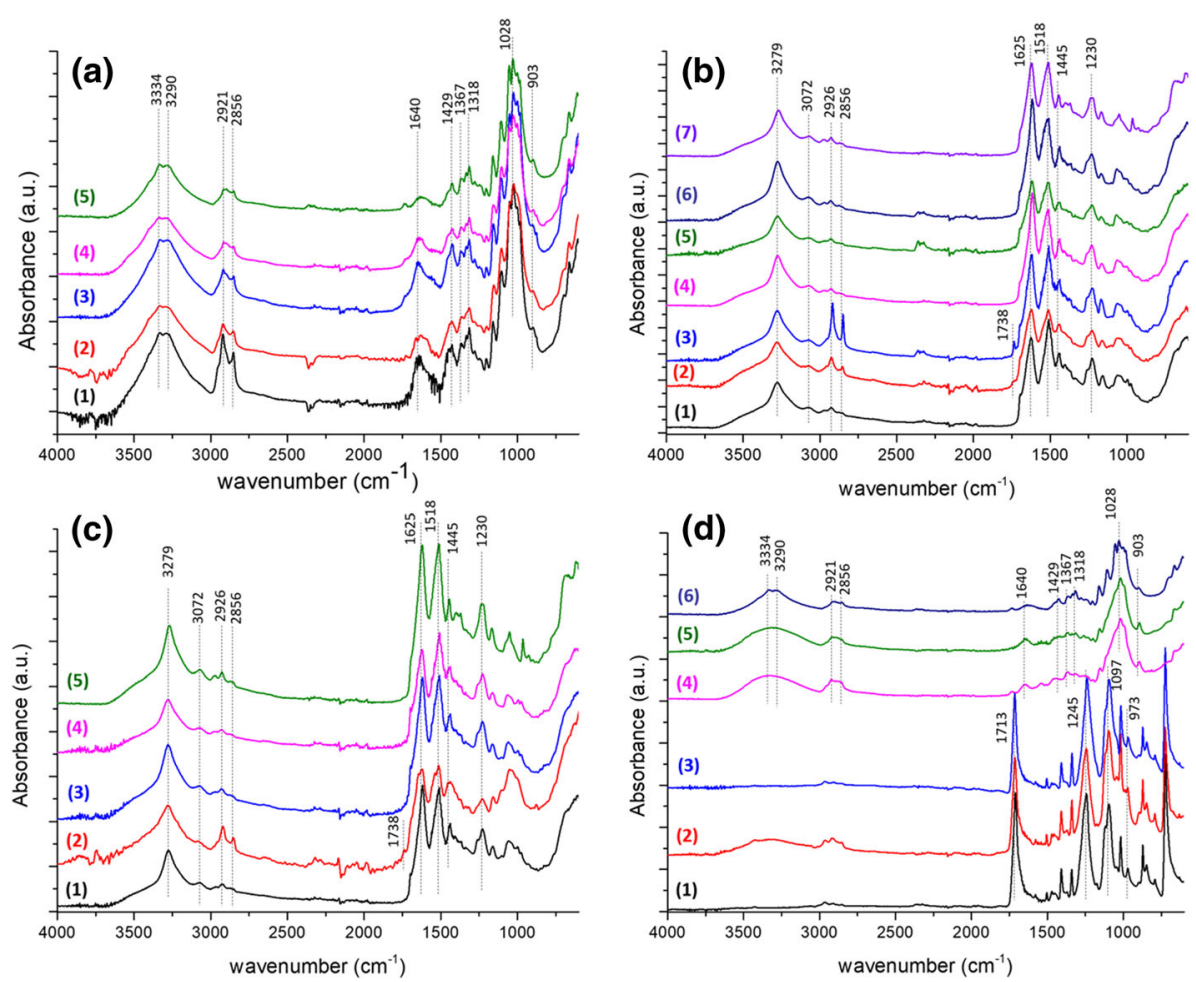

Fig. 3 Infrared spectra corresponding to: (a) (1) lining cope, (2) interlining cope, (3) lining chasuble, (4) interlining chasuble, (5) cotton standard; (b) (1) fabrics cope, (2) metal thread cope, (3) yellow fibers cope, (4) pink fibers cope, (5) blue fibers cope, (6) green fibers cope, (7) silk standard; (c) (1) fabrics chasuble, (2) metal thread chasuble, (3) pink fibers chasuble, (4) green fibers chasuble, (5) silk standard; (d) (1) new lining, (2) core of the new gallon, (3) polyester standard, (4) green fibers of the new gallon, (5) core of the new metal thread, (6) cotton standard

C-O stretching vibration of polysaccharides $[14,16]$ and that at $903 \mathrm{~cm}^{-1}$ to the beta-linkage of cellulose [14].

The thermal curves corresponding to the lining and interlining of the cope and the chasuble showed the presence of cotton in both vestments (Fig. S1). The mass losses occur between 270 and $450{ }^{\circ} \mathrm{C}$ with maximum rates at ca. $360{ }^{\circ} \mathrm{C}$ that are related to the cellulose decomposition.

The fabrics and the core of the metal threads were composed of silk, which is a polyamidebased fiber (Fig. 3b and c). This was very common in liturgical vestments studied in other places [5, 8]. Signals at 3279 and $3072 \mathrm{~cm}^{-1}$ corresponded to $\mathrm{N}-\mathrm{H}$ stretching vibrations of amide A and amide B groups [17, 18]. The intensity of the bands at 2926 and $2856 \mathrm{~cm}^{-1}$, assigned to $\mathrm{CH}_{2}$, was very high in the case of the yellow fiber and also in the infrared spectra collected on the metal threads from the cope (Figs. 3b (2),(3)) and chasuble (Fig. 3c (2)) (the core is a yellow fiber). This fact could be associated with the presence of any component employed, such as a characteristic dye or mordant (binder) employed in the dyeing process. In this case, the signals were assigned to the presence of wax, as will be detailed in the following sections. In addition, only in these three samples, a signal at $1738 \mathrm{~cm}^{-1}$ was observed and assigned to the presence of $\mathrm{C}=\mathrm{O}$ stretching of carboxylic groups involved in an ester linkage. This vibration could be attributed to the monoesters present in beeswax [19]. 

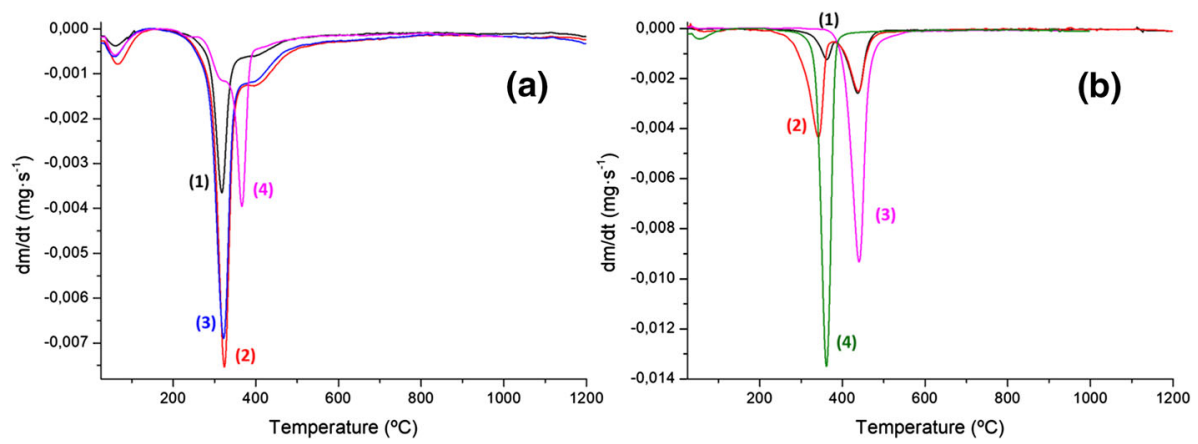

Fig. 4 DTG curves corresponding to: (a) (1) gallon cope, (2) capillo, (3) gallon chasuble, (4) silk standard; (b) (1) new gallon, (2) new metal thread, (3) polyester standard, (4) cotton standard

Bands at 1625 and $1518 \mathrm{~cm}^{-1}$ were associated with amides $\mathrm{C}=\mathrm{O}$ stretching and $\mathrm{C}-\mathrm{N}-\mathrm{H}$ bending vibrations [18]. The signal at $1445 \mathrm{~cm}^{-1}$ was assigned to $\mathrm{CH}_{2}$ scissoring and that at $1230 \mathrm{~cm}^{-1}$ to $\mathrm{N}-\mathrm{H}$ bending, $\mathrm{C}-\mathrm{N}$ stretching and $\mathrm{C}-\mathrm{C}$ stretching vibrations $[17,20]$.

The three thermal curves corresponding to the gallon cope (Fig. 4a (1)), capillo fringes (Fig. 4a (2)) and gallon chasuble (Fig. 4a (3)) showed an important mass loss at $325^{\circ} \mathrm{C}$, that corresponded to the decomposition of amino acid groups and the breakdown of the peptide bonds of the silk fibers $[16,21]$. This temperature was lower than that collected from silk fabrics used as a reference material (Fig. $4 \mathrm{a}(4)$ ), situated at $340{ }^{\circ} \mathrm{C}$. The maximum of DTG was slightly lower due to the deterioration happening over time, which can diminish the temperature of decomposition [21].

\subsubsection{Restoration materials}

Regarding the restoration materials, the new lining (1) and the core of the new gallon (2) were made with polyester (Fig. 3d (1)-(3)). The bands at $1713 \mathrm{~cm}^{-1}$ and at $1245 \mathrm{~cm}^{-1}$ were assigned to the asymmetric $\mathrm{C}=\mathrm{O}$ stretching $[22,23]$ and to the $\mathrm{C}-\mathrm{O}$ stretching vibrations [22]. The signal at $1097 \mathrm{~cm}^{-1}$ corresponded to C-O-H bending [23], and those at $1020 \mathrm{~cm}^{-1}$ to $\mathrm{O}=\mathrm{C}-\mathrm{O}-\mathrm{C}$ or secondary alcohols and at $973 \mathrm{~cm}^{-1}$ to $\mathrm{C}=\mathrm{C}$ stretching [22]. Other parts such as the green fabrics of the gallon (4) or the core of the new metal thread (5) were fabricated with cotton (Fig. 3d (4)-(6)).

The thermal curves fully matched with those of polyester (Fig. 4b (3)) and cotton (Fig. 4b (4)) for both the new gallon (including the core and the green fabrics) (Fig. $4 \mathrm{~b}$ (1)) and the new metal thread (also with some part of lining) (Fig. 4b (2)). Obviously, the degradation processes did not happen in this case and the temperatures matched with the standard samples. The stage in which the most weight loss occurred was between 390 and $470{ }^{\circ} \mathrm{C}$. This loss was due to the degradation to breaking of the bonds within polyester [23].

\subsection{Metal threads}

\subsubsection{Cope threads}

In both garments, cope and chasuble, a similar and homogeneous disposal of the strips in a S-twisted form around the yellow silk core was observed except in some areas of the chasuble gallon. 

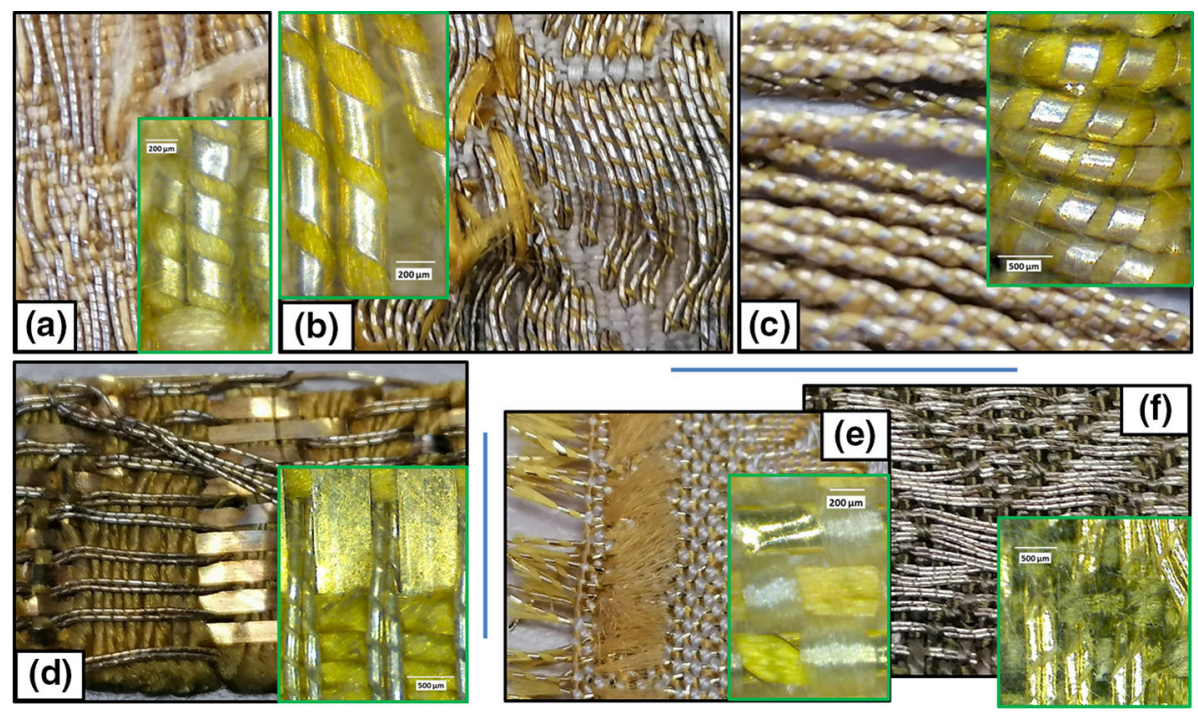

Fig. 5 Micrographs by optical microscopy: (a) gallon cope, (b) metal thread cope, (c) capillo, (d) gallon chasuble, (e) new metal thread, (f) new gallon

In the cope, the widths of the threads were ca. $250 \mu \mathrm{m}$ in the gallon (Figs. 5a and 6a, Table 1) and higher (ca. $275 \mu \mathrm{m}$ ) in the case of the metal threads (Figs. $5 \mathrm{~b}$ and $6 \mathrm{~b}$, Table 1). The EDX analyses of the gallon showed metal strips with compositions of $91 \%$ of silver and $9 \%$ of gold (Fig. 7a, Table 1) Silver was detected thanks to its peak at $2.98 \mathrm{keV}$, assigned to the $\mathrm{L} \alpha$ line. Peaks at 2.12 and $9.71 \mathrm{keV}$ corresponded to the $\mathrm{M} \alpha$ and $\mathrm{L} \alpha$ emission lines of the gold. Over the metal appeared small particles (Fig. 6c), constituted by silver and chloride. The elemental chemical mapping (Fig. 7b) showed the distribution of silver in the inner layer of the sample, stretch lineal marks of gold over silver and the particles of silver chloride laid externally on the metal. The EDX analysis of the metal thread of the cope showed $74 \%$ of silver and $26 \%$ of gold, and also chlorine and sulfur. The gold percentage was higher than in other metal threads studied (Table 1). Similarly, to the gallon, the surface of the metal thread showed lineal scratches responsible for the heterogeneous distribution of silver and gold, which was shown in the mapping analysis (Fig. 7c). The disposal of the external and internal layers and components was clearly determined by SEM images (Figs. 6c and 7b). Other authors have employed cross sections to characterize the interior as well as the surface layers of the metal threads [24], some using focused ion beam [25]. Also, EDX experiments could be carried out at different accelerating voltages in order to determine the in-depth composition [26].

Figure $8 \mathrm{a}$ and $\mathrm{b}$ shows the XRF spectra of the gallon cope and the metal thread cope. Silver, gold and copper were observed (the copper thanks to the peak at $8.05 \mathrm{keV}$ corresponding to $\mathrm{K} \alpha$ signal). Chlorine was mainly detected in the gallon (as was also observed by SEM-EDX), where more silver was observed (Fig. 8a). A higher corrosion degree was detected in this zone of the cope due to the possible presence of silver chloride [27]. Gold was detected mainly in the metal thread compared to the gallon (Fig. 8a and b). The results by XRF matched in a semiquantitative way with those by SEM-EDX.

In the case of the fringes of the capillo, the diameters of the metal threads (ca. $250 \mu \mathrm{m}$ ) (Figs. 5c and 6d, Table 1) and the composition (92.5\% of silver and $7.5 \%$ of gold) were 


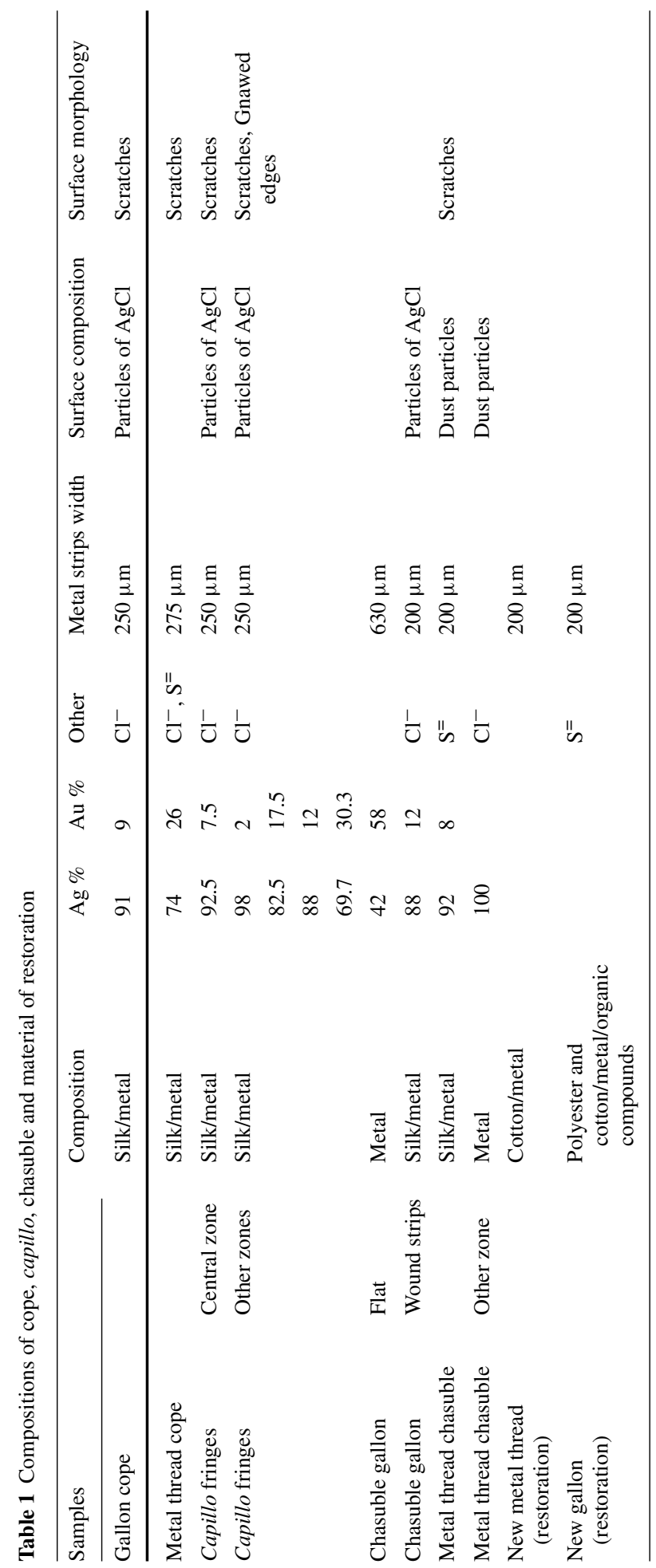




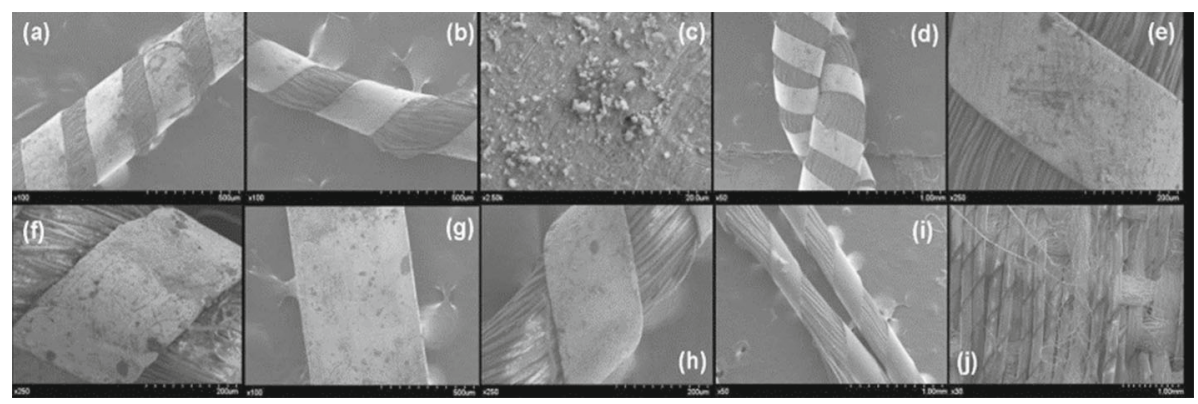

Fig. 6 SEM images corresponding to: (a) gallon cope, (b) metal thread cope, (c) particles in the surface of the gallon cope, (d, e) capillo, (f) capillo (other zone), (g) gallon chasuble (flat), (h) metal thread chasuble, (i) new metal thread, (j) new gallon

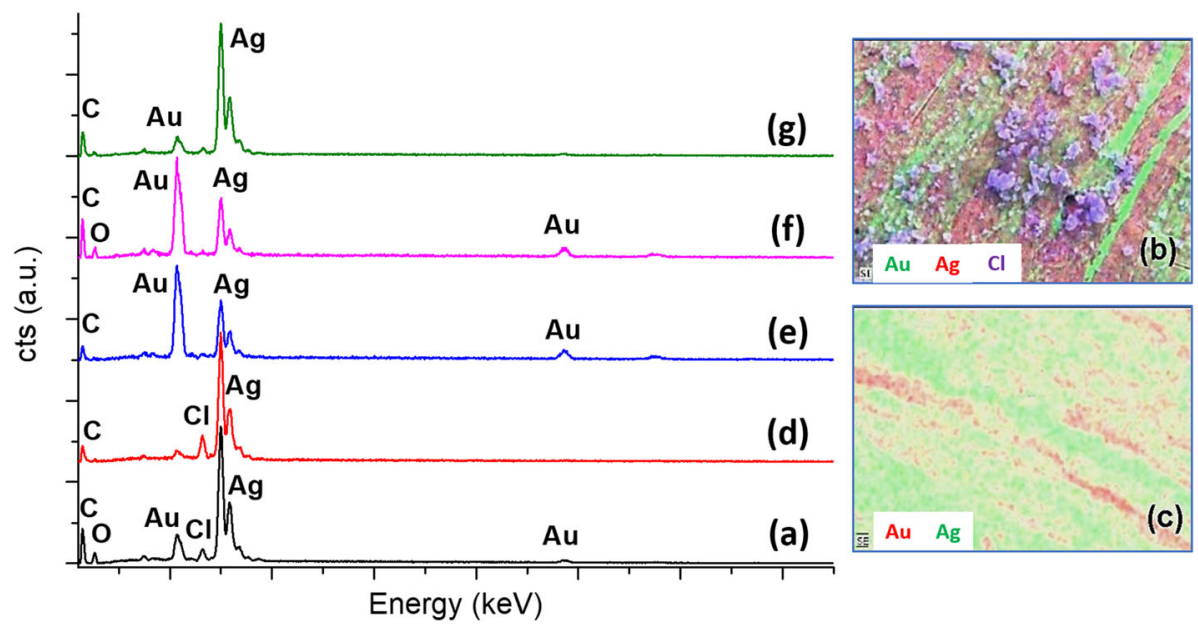

Fig. 7 EDX spectra of: (a) gallon cope, (d) capillo (inner layer), (e) capillo (brilliant spots), (f) gallon chasuble, (g) gallon chasuble (strips wound); mappings of: (b) gallon cope, (c) metal thread cope

similar to those of the gallon of the cope. By XRF, the composition of the capillo (Fig. 8c) was very similar to that of the cope gallon. The surface of the fringes showed scratches and some brilliant spots (Fig. 6e). The chemical analysis carried out at the bottom of the scratches (inner layer) showed the presence of silver (Fig. 7d), whereas the brilliant spots were constituted by a high percentage of gold (Fig. 7e). Chlorine was also detected together with silver (Fig. 7d). In other parts of the fringes of the capillo, the metal showed scratches and some edges gnawed (Fig. 6f). The deeper zones analyzed showed a higher percentage of silver, increasing the percentage of gold in the upper zones (Table 1). Some variations in the compositions were observed in the EDX analyses performed in different areas of the capillo fringes (Table 1).

\subsubsection{Chasuble threads}

Two different types of the metallic strips were observed for the chasuble: some flat metal sheet with a width of ca. $600 \mu \mathrm{m}$ (Figs. 5d and 6g), and strips wound around the yellow fiber of silk with a diameter minor than those found in the cope; the values were around $200 \mu \mathrm{m}$ 


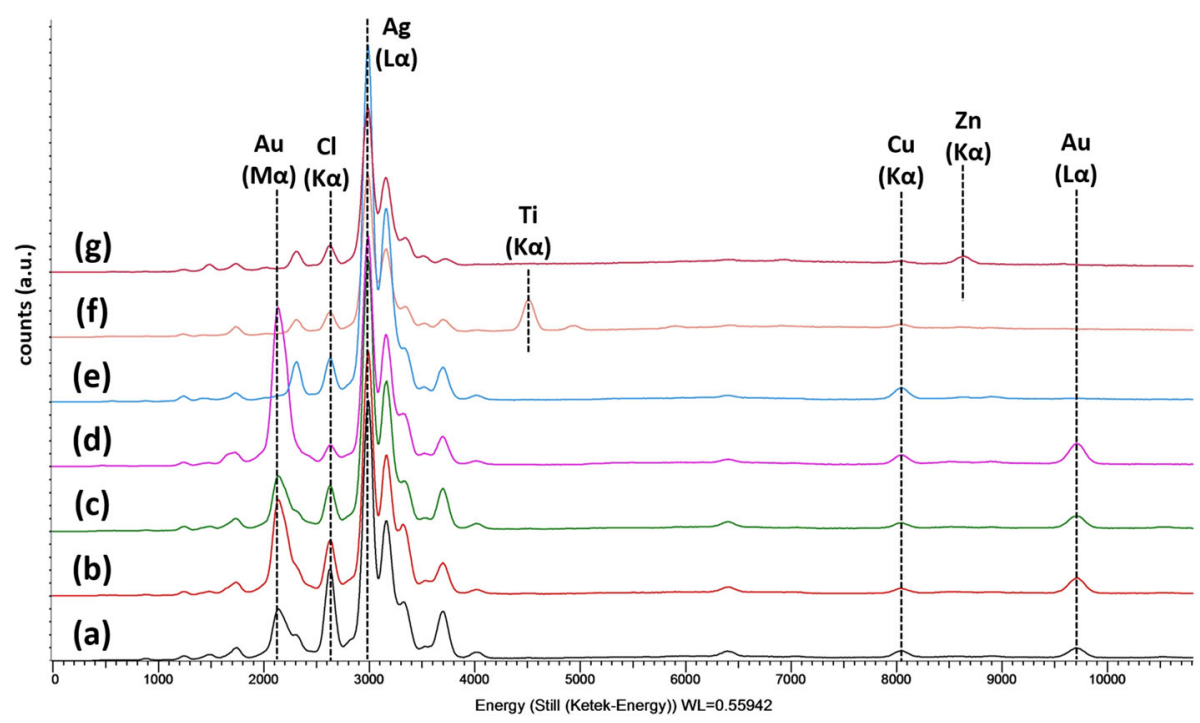

Fig. 8 XRF spectra corresponding to: (a) gallon cope, (b) metal thread cope, (c) capillo, (d) gallon chasuble, (e) metal thread chasuble, (f) new gallon, (g) new metal thread

(Figs. 5d and 6h). The use of two different types of ornamentation clearly showed the higher quality of this piece and the best performance of the artists in its fabrication. In the case of the chasuble gallon, the main strips used were the flat ones (sheets), which were constituted by $42 \%$ of silver and $58 \%$ of gold (Fig. 7f, Table 1), whilst the strips wound around the silk were constituted by $88 \%$ of silver and $12 \%$ of gold (Fig. $7 \mathrm{~g}$, Table 1 ). Regarding the chasuble metal threads, their morphology and composition were very similar to those described for the metal threads cope, although in some parts, only silver was detected (Table 1). Chlorine and sulfur were punctually observed in the chasuble and dust on the surface (Table 1).

In the case of the studies of chasuble by XRF, the gallon (Fig. 8d) presented the highest amount of gold and the thread the lowest (Fig. 8e). As aforementioned, these results could suggest a best knowledge and performance in the fabrication of the chasuble, in which gold was only used for the gallon and not in the threads forming part of the fabrics. Again, the results obtained by XRF and EDX coincided.

The results obtained by SEM-EDX and XRF were also ratified by XRD. Gold and silver have face-centered cubic structure with very similar cell parameters: $4.079 \AA$ in gold (PDF 04-0784) and 4.072 $\AA$ in silver (PDF 02-1098). Gold forms continuous solid solutions with silver and copper; both have the same crystallographic structure as the gold [27]. The signal of the (200) planes of silver was located at $2 \theta=44.1^{\circ}$ and that of gold at $2 \theta=44.4^{\circ}$ (Fig. 9). Mainly gold was detected for the gallon chasuble. In the metal thread of the chasuble, silver was clearly detected and a shoulder that was assigned to gold. For the other pieces (gallon cope and capillo fringes), signals of gold and silver were detected (Fig. 9). Although the formation of solid solutions could not be discarded, based on SEM mappings and EDX punctual analyses it seemed that two different layers were detected: the internal formation of silver and the external of silver and gold, although this latter disappeared in some areas due to the scratches observed. 


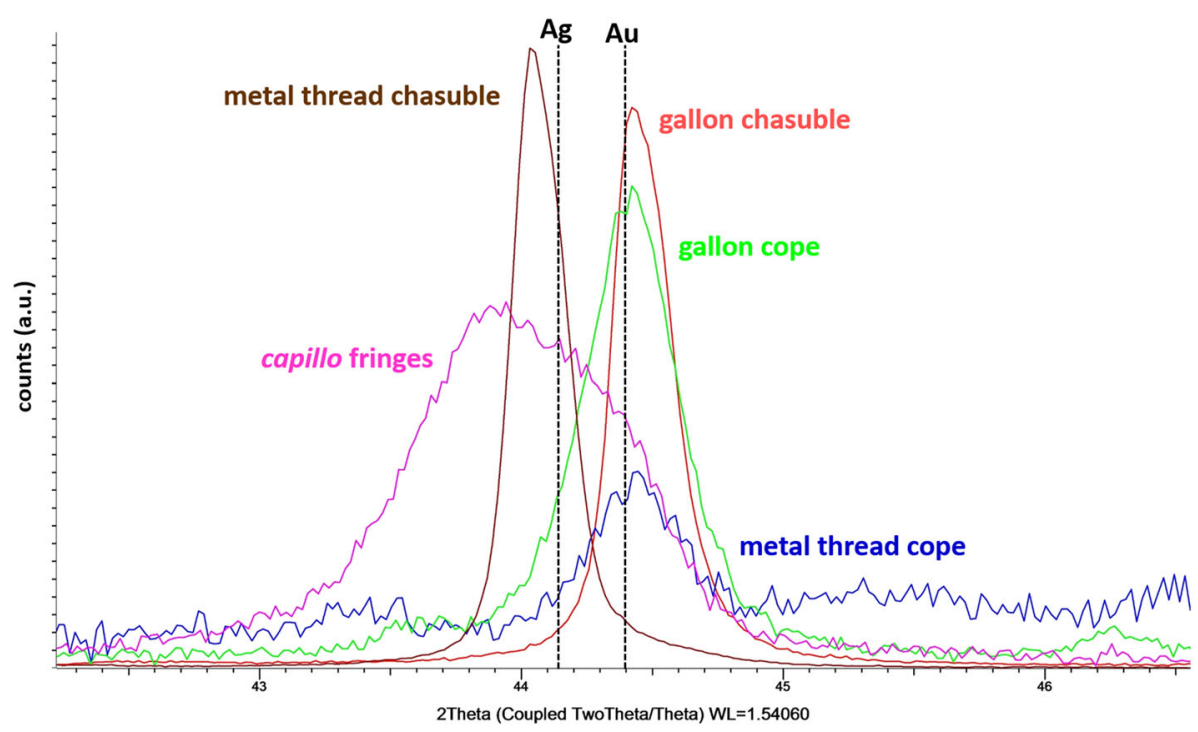

Fig. 9 XRD diffractograms collected from the cope (gallon, metal thread), capillo and chasuble (gallon, metal thread)

\subsubsection{Restoration threads}

The diameters of the metal threads in the form of strips employed for restorations were ca. $200 \mu \mathrm{m}$ (Figs. 5e and 6i), similarly to those of the cope. The core was formed by cotton as was also found by FTIR and thermal analysis. In the case of the gallon restoration, the width was ca. 200 and the core was composed of cotton and polyester fabrics (Figs. 5f and 6j). Cellulosic fibers, very possibly cotton, joined the different threads. By XRF, mainly silver (Fig. 8f) but also titanium was detected in the spectra collected ( $\mathrm{K} \alpha$ signal at $4.5 \mathrm{keV})$. The EDX analysis showed the presence of mainly silver (by both techniques, EDX and XRF), aluminum and nitrogen by EDX, and silver and zinc ( $\mathrm{K} \alpha$ signal at $8.6 \mathrm{keV})$ by $\mathrm{XRF}$ in the metal thread (Fig. 8g).

\subsection{Colored fabrics}

\subsubsection{Colorimetry studies}

Both garments were decorated, as usual happened in the liturgical vestments $[2-5,8,10]$.

The lining (1) was greenish in the cope (value of a* of -3.03) and brownish in the chasuble (values of $\mathrm{a}^{*}$ of 4.70 and $\mathrm{b}^{*}$ of 24.02). The lightness values were higher for the chasuble $\left(\mathrm{L}^{*}=68.42\right)$ (Fig. 2a and 2c, Table 2). The new lining (1) (Fig. 2b) used for restoration had values of $a^{*}$ closer to zero and of $b^{*}$ minor than that of the chasuble, so provided a yellowish tone in the final appearance; the lightness values of the new lining were higher $\left(\mathrm{L}^{*}=87.36\right)$ than the originals (Table 2).

Although the interlining (2) and the fabrics (3) were visually very similar for both pieces (Fig. 2a and 2c), the chasuble interlining presented higher values of $\mathrm{a}^{*}(4.02 \mathrm{vs} 2.90)$ and $\mathrm{b}^{*}$ (24.96 vs 21.94) and the cope fabrics higher values of $b^{*}$ (22.75 vs 18.41) (Table 2), so the tone of the cope was more yellowish and of the chasuble was more brownish. 
Table 2 Colorimetry studies of the cope, chasuble, colored fabrics and restoration (new) materials

\begin{tabular}{llrrr}
\hline \multirow{2}{*}{ Lining } & & \multicolumn{1}{l}{$\mathrm{L}^{*}$} & \multicolumn{1}{c}{$\mathrm{a}^{*}$} & \multicolumn{1}{c}{$\mathrm{b}^{*}$} \\
& Cope & 51.24 & -3.03 & 8.32 \\
& Chasuble & 68.42 & 4.70 & 24.02 \\
Interlining & Restoration & 87.36 & 2.91 & 14.73 \\
& Cope & 65.26 & 2.90 & 21.94 \\
Fabrics & Chasuble & 60.08 & 4.02 & 24.96 \\
& Cope & 66.89 & 2.56 & 22.75 \\
Metal threads & Chasuble & 70.71 & 2.31 & 18.41 \\
& Cope & 57.50 & 2.24 & 30.15 \\
& Chasuble & 64.53 & 2.41 & 15.73 \\
Gallons & Restoration & 75.73 & 2.69 & 26.70 \\
& Cope & 60.06 & 1.78 & 30.10 \\
& Capillo fringes & 60.16 & 1.90 & 29.89 \\
& Chasuble & 66.77 & 2.64 & 27.34 \\
Colored fibers & Restoration & 65.39 & 0.20 & 26.67 \\
(Cope) & Blue & 56.20 & -1.61 & 4.59 \\
& Green & 59.77 & -4.97 & 29.68 \\
& Yellow & 66.58 & 3.93 & 42.91 \\
& Pink & 55.63 & 16.08 & 17.54 \\
\hline
\end{tabular}

The metal threads (4) and gallons (5) (Fig. 2a and 2c) were characterized by a core of fibers and metal strips wound around them as usual in this type of embroidery [5, 8, 24-28]. The internal yarns of the two pieces (Fig. 5a-d) were visually yellow. The values of $b^{*}$ in metal threads, gallons and fringes were high. Again, the values of $b^{*}$ were higher for the cope; the higher values of $a^{*}$ and minor of $b^{*}$ corresponded to the chasuble (Table 2), very possibly for the influence of the fabrics underlayer. The new metal thread (4) for restoration (Fig. 2b) provided a very similar tone but with higher lightness (76 vs 58 or 65 ). In the case of the new gallons (5) for restoration (Fig. 2b), which was placed in the cope, the hue was clearly less reddish, with values of $a^{*}$ close to zero. Greenish yarns were observed with the naked eye and with optical microscopy (Figs. 2b and 5f).

The cope was more richly decorated with green, blue, yellow and pink yarns (Fig. 1). Fibers of different colors (blue, green, yellow and pink) from the cope were studied (Table 2). Blue color was the darkest (minor value of $\mathrm{L}^{*}$ ca. 56) together with the pink (56). Values of $\mathrm{a}^{*}$ were negative for blue and green fibers $(-1.61$ and -4.97 , respectively). The chromatic values for the yellow fibers were similar to those of the gallons and the metal threads of the cope in order to simulate the gilding tone, although the value of $b^{*}$ was higher (43) (Table 2).

\subsubsection{Dyes recognition}

SEM applied to the blue fiber of the cope showed the presence of silk fibrous (Fig. 10a), and the micro-Raman study of this blue color showed scattering peaks at 1700, 1574, 1363, 1309, $1249,1014,757,597$ and $251 \mathrm{~cm}^{-1}$, which matched with the Raman spectrum of indigo [29, 30]. A comparative figure with the spectrum obtained in our study in blue fibers and the 

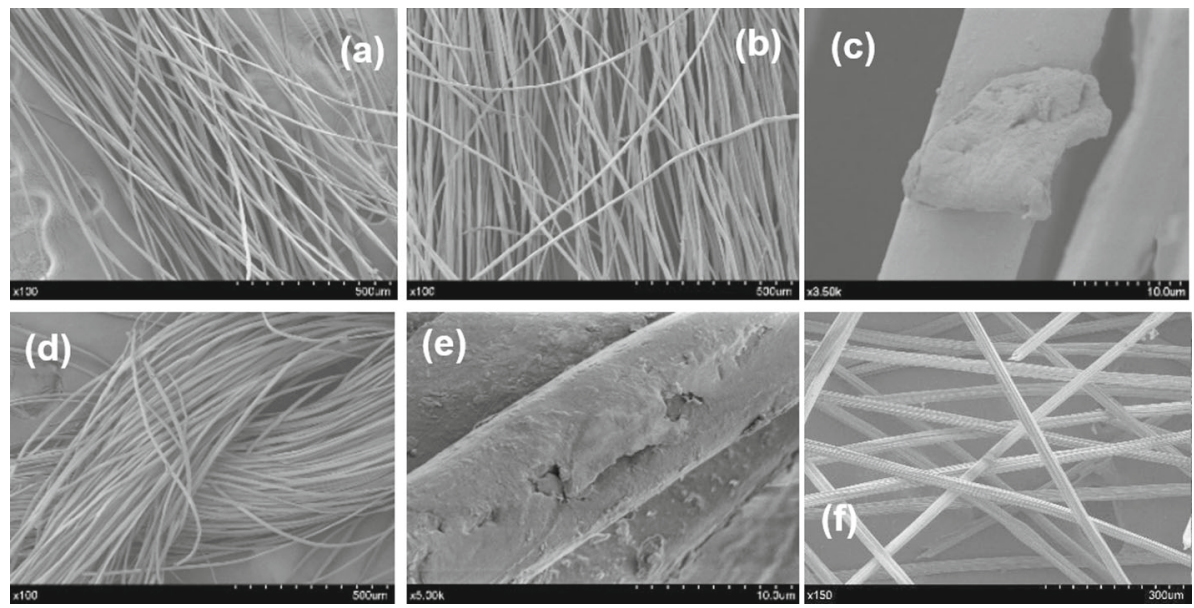

Fig. 10 SEM images corresponding to: (a) blue fibers, (b) green fibers, (c) small particles on green fibers, (d) yellow fibers, (e) external layer on the yellow fibers, (f) new metal thread

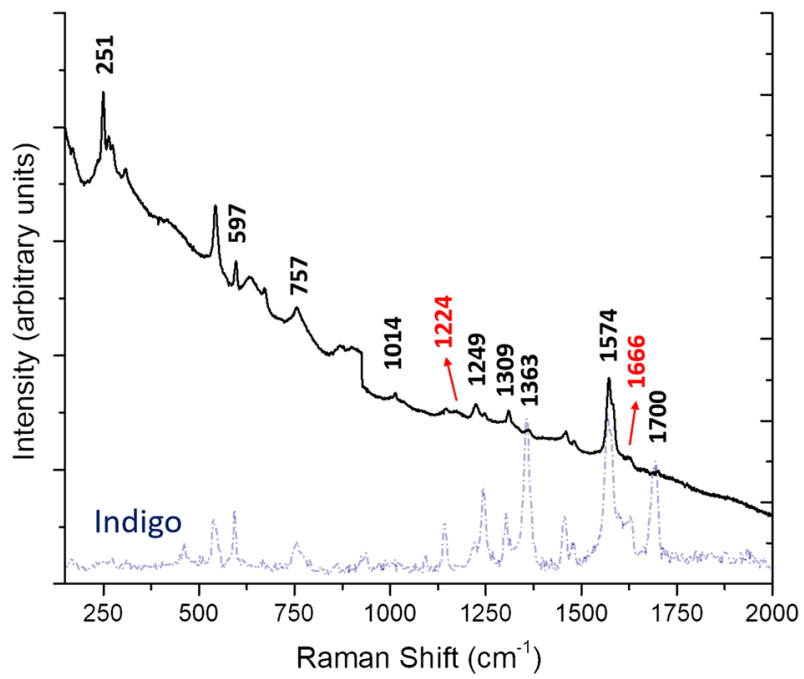

Fig. 11 Raman spectrum corresponding to the blue fibers from the cope

pattern sample of indigo is shown in Fig. 11. The signals at 1666 and $1224 \mathrm{~cm}-1$ could be assigned to the amide vibrations of silk structure [29].

The SEM study of green fibers showed a morphology similar to the blue ones (Fig. 10b). Small particles deposited over the fiber have also been observed (Fig. 10c). The EDX analysis of these particles showed the presence of $\mathrm{Na}, \mathrm{Al}, \mathrm{K}, \mathrm{Cl}, \mathrm{S}$ and $\mathrm{Ca}$ together with $\mathrm{C}, \mathrm{O}$ and $\mathrm{N}$, which could be due to dust or the rest of a mordant, very possibly alum $\left(\mathrm{KAl}\left(\mathrm{SO}_{4}\right)_{2} \cdot 12 \mathrm{H}_{2} \mathrm{O}\right)$. The Raman spectroscopy showed the presence of indigo, similarly to the blue color. However, the green color may be attributed to a mix of indigo and a yellow dye that did not yield a strong Raman spectral component. 


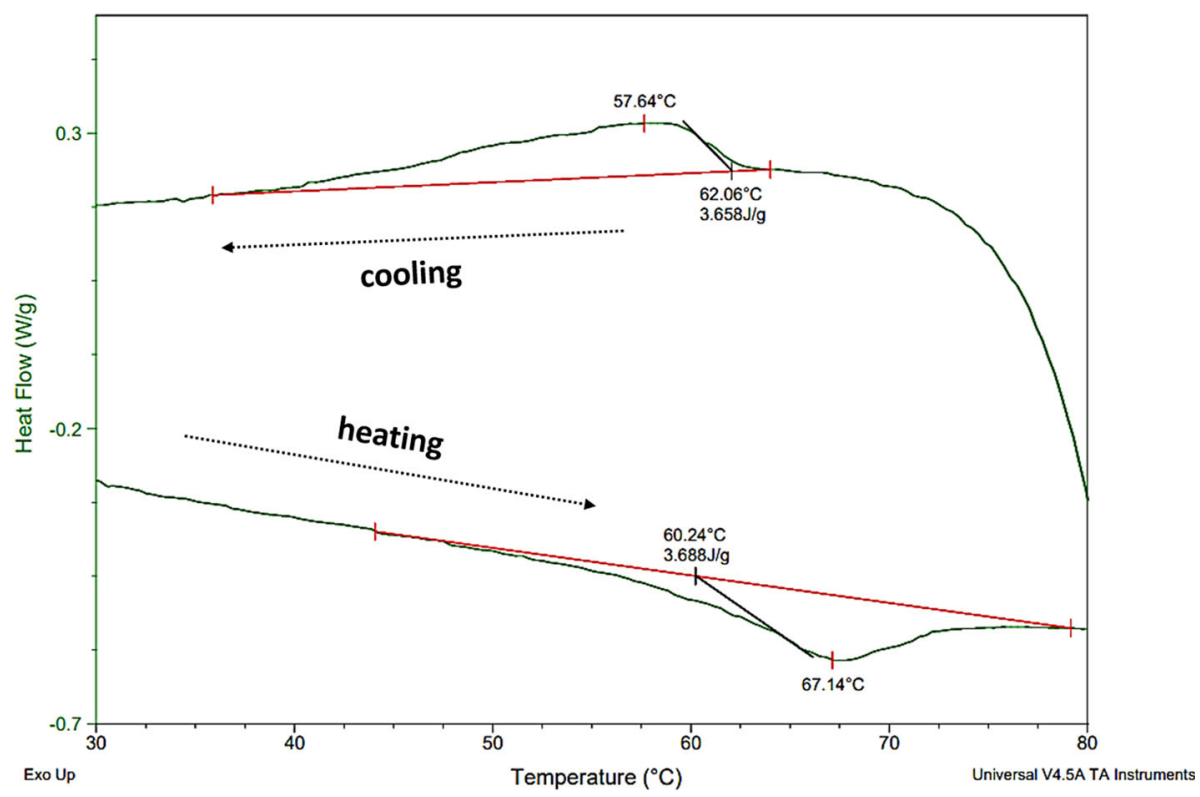

Fig. 12 DSC curves obtained from the yellow fibers from the cope

The SEM observation in the yellow fibers showed similarity with those two samples previously studied (Fig. 10d). The Raman scattering of the yellow fibers yielded a poorquality, unidentifiable Raman spectra. However, the fibers were covered by a layer of other components (Fig. 10e). This layer may be attributed to an incomplete degumming process typically from pre-industrialized processes or to the wax used to protect and strengthen the embroidery thread, frequently used during the embroidery manufacture, and possibly responsible for the yellow color in these fibers. Differential scanning calorimetry has been applied to the wax analysis in artworks in order to detect the absorption (endothermic) or liberation (exothermic) of heat [31,32]. The yellow fiber sample was heated between 30 and $80^{\circ} \mathrm{C}$ and after cooling in this temperature range. The treatment was repeated four times. The heating between 30 and $80{ }^{\circ} \mathrm{C}$ showed an endothermic effect with maximum at $67.14{ }^{\circ} \mathrm{C}$, and the cooling between 80 and $30{ }^{\circ} \mathrm{C}$ showed an exothermic peak with maximum at $57.64{ }^{\circ} \mathrm{C}$ (Fig. 12). These effects were attributed to melting and crystallization processes, respectively, of the wax present in the sample. These effects were reported in the several heating-cooling cycles carried out. The FTIR analysis also confirmed the presence of wax in the yellow fibers (Fig. 3b (3)).

Regarding the pink fibers, the morphology was very similar to the previous fibers studied. Raman scattering on this fiber was weak, yielding a poor-quality Raman spectrum, and was not possible to detect the compounds responsible for the color. On the surface of the fibers, appeared particles constituted by a high content of $\mathrm{C}$ and also $\mathrm{O}, \mathrm{N}, \mathrm{Al}, \mathrm{S}, \mathrm{Cl}, \mathrm{K}, \mathrm{Ca}$ and $\mathrm{Ba}$ were present, which was attributed to the red dye used to obtain this color and/or to the treatment of the textile fibers with a solution of mordant during the dyeing process, again suspected alum.

SEM images of the colored fibers of the restoration material (new green fabrics of the gallon of the cope) showed morphology of fibers compatible with polyester (Fig. 10f). 


\section{Discussion}

The lining and interlining in both the cope and the chasuble were done by cotton. The studied samples from the embroiders of the gallon and threads of the cope, the capillo fringes, and the gallon and threads of the chasuble showed metal strips wound around fibrous silk. All the textile fibers of these samples were confirmed as degummed silk fibers. The maximum of DTG peaks corresponding to the decomposition of the fibers was lower than those found for the standard samples due to deterioration and changes over centuries [21]. In this sense, the liturgical vestments studied were historically dated in the seventeenth-eighteenth centuries.

Regarding the metallic parts, a single metal thread core, two metal threads or even several threads with the core of silk threads have been observed. In some samples appeared also metal sheet strips without a fibrous core of silk. The threads width values ranged between 250 and $275 \mu \mathrm{m}$. A rough estimation of the metal layer thickness of the strips indicated values very low (ca. 1-2 $\mu \mathrm{m}$ ). Accurate thicknesses data for the gold layer could not be obtained because they were very thin and were randomly distributed on the wire surface. Similar results have been also found in other studies [5, 33]. According to the EDX analysis, the metal strips were gilt silver constituted by about $90 \%$ silver and $10 \%$ gold. Two strips layers have been identified: the upper with silver and gold and the down constituted only by silver, which may be due to the manufacture in order to reduce the prices. The samples with the highest values of gold were those with sheet morphology, in which the percentages were ca. $60 \%$.

Different amounts of gold and silver and copper were found by using XRF, although results matched in a semiquantitative way with those obtained by using SEM-EDX. The differences in the results between XRF and EDX could be attributed to the different depth penetration of X-rays $(100-200 \mathrm{~mm})$ and electrons $(0.5 \mathrm{~mm})$ [9]. The amounts of copper were usually very low.

Similar artworks from other places and centuries have also shown this elemental composition. The metallic parts of an Italian chasuble from the fifteenth century were composed of different amounts of silver, gold and copper [8]. A Portuguese liturgical cope pluvial from the sixteenth century was fabricated with silver and copper [5]. Gold, silver and copper were also found in the metal threads from Croatian liturgical vestments dated to the seventeenth-twentieth centuries [9]. The absence of aluminum in the garments studied ratified their datation. The voluntary use of aluminum was dated around the middle of the nineteenth century [8].

Regarding the manufacturing process, the method of "cast, drawn and rolled" threads was that most matched with the microscopy observations of our samples. In this technique, a gilded silver wire was flattened between two rollers, and metals with a double-sided gilding were produced and wound around the textile fibers $[5,11]$. The other production technique was called "beaten and cut," in which a top-gilded block was beaten into a thin sheet and cut into strips [5]. The final metal threads were made by combining the fibrous core and the metal thread in a spinning process $[5,14,15]$.

The study showed the presence of silver chloride and silver sulfides over the metal strips. The formation of this salt may be due to the interaction between $\mathrm{Ag}^{+}$with $\mathrm{Cl}^{-}$ions [27, 34]. The presence of chlorides may be due to an incorrect neutralization of $\mathrm{HCl}$ produced by the use of thiourea for cleaning [34] and also to cleaning processes with inadequate solutions [27]. Sulfur in low percentage has also been detected. The silver surface very possibly reacted with gaseous sulfur compounds $\left(\mathrm{H}_{2} \mathrm{~S}\right.$, OCS and others) present in the atmospheric environment, producing $\mathrm{Ag}_{2} \mathrm{~S}$ in a process named tarnishing [21,35]. The SEM images showed scratches and abrasions over the metal strips. Sometimes the cleaning methods were so aggressive that even removed the gilding coating as was shown in the mappings performed $[36,37]$. These 
treatments may be responsible for the heterogeneous distribution of gold and silver detected on the metal strip surface.

The restoration of these liturgical vestments consisted of changes of the lining, replacement of the deteriorated gallons, and the fixation and consolidation of the fabrics in some zones. The restoration metal threads and gallons were studied. The results indicated that the material of restoration was of minor quality compared with that of the original material. The original material was constituted by metal strips wound around fibrous silk. The restoration material was manufactured using strips of silver and other cheaper components such as aluminum or zinc wound around a fibrous core of cotton and polyester. Interestedly, in one of the samples of the restoration gallon, silver was detected by EDX, using $30 \mathrm{kV}$ as acceleration voltage, instead of $20 \mathrm{kV}$ as was usually applied in this work, which meant that silver was in the core and then was covered by a thick layer of organic compound.

In the twentieth and twenty-first centuries, the quality of the threads decreased. Metallic threads from the last decades are preferentially silvered, although it was also employed less noble metal such as brass, nickel or zinc [8, 11, 29].

The cope was the garment more richly decorated with blue, green, yellow and pink yarns (Fig. 1a-c). Samples of all these areas were studied in this work. The SEM images showed the presence of silk fibrous in the studied samples. Several experimental techniques have been used to characterize the dyes used in historical textiles [5, 10, 29]. The micro-Raman spectroscopy study confirmed the presence of blue indigo, the dye used to get the blue color in our samples. The employment of indigo in Europe did not occur until about 1602. From the beginning of the eighteenth century, its valuable properties became gradually recognized throughout Europe [38]. This dye was also used to obtain the green color probably mixed with a yellow dye that did not yield a strong Raman spectral and that was not possible to characterize. Indigo has been used in other embroideries [10,11]. In the yellow fibers, a surface layer was responsible for the color. Differential scanning calorimetry characterized the presence of wax in these samples, used to get the yellow color. The FTIR study also confirmed the presence of wax in the fibers of this color and also in the metal threads. In our case, it is possible that a yellow dye was employed in yellow and green fibers, which mixed with indigo resulted in the green color. As mentioned in the literature [5, 38, 39], some components forming part of the plant extracts were unidentifiable in historical textiles. Among the different dyes, weld, originating from the Reseda luteola L., was reported to be the oldest and one of the most used dyestuff in Europe for dyeing silk and wool yellow [40].

The SEM-EDX analysis performed on the colored samples showed that alum was the mordant employed in the dyeing process. This compound has been the mordant most extensively used [5, 41].

\section{Conclusions}

Spanish liturgical vestments have not been largely studied from a scientific point of view. Two pieces from the seventeenth-eighteenth centuries, a cope and a chasuble from Andalusian, in the Southern Spain, were largely studied by techniques usually employed in the field of materials science, such as optical microscopy, infrared spectroscopy with ATR, thermal analysis (TG-DTA and DSC), SEM-EDX, XRF and micro-Raman spectroscopy.

Lining and interlining of the garments were composed of cellulosic fibers (cotton) and the core of the metal threads by silk. The composition of the metal thread was based on the presence of silver, gold and little amounts of copper. In the case of the chasuble gallon, 58\% of gold (the highest percentage) was detected in the ornamentation of this embroidery in the 
form of sheets. Otherwise, the gold percentage in the metal threads of the cope was higher (ca. 25\%) than in the gallon of the cope (ca. 10\%), metal thread chasuble (from 0 to ca. 10\%) or chasuble gallon in the form of strips wound around the fibers (ca. 10\%). In the capillo fringes, the amount of gold depended on the zone and layer analyzed ranging the values from 2 to $30 \%$. Two strips layers have been identified: the upper with silver and gold, and the down constituted only by silver. In the surface of the pieces, scratches were observed and also particles of silver chloride, very possibly due to an incorrect mechanical and chemical cleaning.

Indigo was detected in the blue and green fibers (possibly mixed with other yellow dye) and also wax in the yellow fiber. Alum was the mordant employed for dying. It would be interesting in the future to employ gas chromatography and/or surface-enhanced Raman to completely know the nature of the yellow dye and wax.

The restoration materials were of minor quality than the original ones: polyester was used.

Supplementary Information The online version contains supplementary material available at https://doi. org/10.1140/epjp/s13360-021-02220-2.

Acknowledgements The main acknowledgement is for Cristina Luzuriaga, from University of Navarra, for her invaluable help in the experiments. Also, the authors acknowledge the parish church of Our Lady of Consolation in El Pedroso for providing the samples, which were collected to perform restoration processes on the artworks (june of 2020).

Author's contribution AD done conceptualization and writing —original draft preparation; AD and JLP$\mathrm{R}$ contributed to methodology, formal analysis, investigation, writing - review and editing, resources and supervision,;

Funding Open Access funding provided thanks to the CRUE-CSIC agreement with Springer Nature.

Data Availability Statement This manuscript has associated data in a data repository. [Authors' comment: The datasets generated during and/or analysed during the current study are available from the corresponding author on reasonable request.]

\section{Declarations}

Conflicts of interest Not applicable.

Open Access This article is licensed under a Creative Commons Attribution 4.0 International License, which permits use, sharing, adaptation, distribution and reproduction in any medium or format, as long as you give appropriate credit to the original author(s) and the source, provide a link to the Creative Commons licence, and indicate if changes were made. The images or other third party material in this article are included in the article's Creative Commons licence, unless indicated otherwise in a credit line to the material. If material is not included in the article's Creative Commons licence and your intended use is not permitted by statutory regulation or exceeds the permitted use, you will need to obtain permission directly from the copyright holder. To view a copy of this licence, visit http://creativecommons.org/licenses/by/4.0/.

\section{References}

1. https://www.vaticanum.com/en/liturgical-vestments. Accesed 5 February 2021

2. J. Braun. Vestments. The Catholic Encyclopedia, vol. 15. (Robert Appleton Company, New York, United States of America, 1912), https://www.newadvent.org/cathen

3. I.A. MacLeod, R.J. Car, J. Cult. Herit. 15, 628 (2014)

4. P. Johnstone, High fashion in the church: the place of church vestments in the history of art from the ninth to the nineteenth century (Maney Publishing, Leeds, 2002), p. 165 
5. T. Ferreira, H. Moreiras, A. Manhita, P. Tomaz, J. Mirao, C.B. Dias, A.T. Caldeira, Microsc. Microanal. 21, 2 (2015)

6. A. Durán Benito, J.M. González García, Hermandad del Santísimo Cristo de la Misericordia y Nuestra Señora de los Dolores de El Pedroso: 50 años (Fundación José Manuel Lara, El Pedroso, Spain, 2004), p. 80

7. M. Jimenez Cristofani, Catálogo Histórico-Artístico de El Pedroso (Sociedad de Desarrollo Local de El Pedroso, El Pedroso, Spain, 1998), p. 96

8. D. Amorello, S. Barreca, M. Bruno, A. Milia, S. Orecchio, A. Pettignano, Microchem. J. 129, 305 (2016)

9. K. Simic, I. Zamboni, S. Fazinic, D. Mudronja, L. Sovic, S. Gouasmia, I. Soljacic, Nucl. Instrum. Methods Phys. Res. Sect. B Beam. Interact. Mater. Atoms 417, 115 (2018)

10. K. Lech, Data Brief 31, 105735 (2020)

11. M. Sepulveda, C. Lemp, J. CarcamoVega, E. CasanovaGonzalez, S. Gutierrez, M.A. MaynezRojas, B. Ballester, J.L. RuvalcabaSil, Herit. Sci. 9(1), 59 (2021)

12. D.A. Badillo-Sanchez, C.B. Dias, A. Manhita, M. Schiavon, Eur. Phys. J. Plus 134(5), 224 (2019)

13. E.S.B. Ferreira, A.N. Hulme, H. McNab, A. Quye, Chem. Soc. Rev. 33, 329 (2004)

14. N. Abidi, L. Cabrales, C.H. Haigler, Carbohyd. Polym. 100, 9 (2014)

15. L.K. Herrera, A. Justo, A. Duran, M.C. Jimenez de Haro, M.L. Franquelo, J.L. Perez-Rodriguez, Appl Phys A 99, 391 (2010)

16. B. De Diego-Diaz, A. Duran, M.R. Alvarez-Garcia, J. Fernandez-Rodriguez, Fuel 245, 240 (2019). https:// doi.org/10.1016/j.fuel.2019.02.051

17. B. Aksakal, Spectrochim. Acta A 152, 629-636 (2016)

18. P. Peets, K. Kaupmees, S. Vahur, I. Leito, Herit. Sci. 7, 93 (2019)

19. M. Maia, A.I.R.N.A. Barros, F.M. Nunes, Talanta 107, 74 (2013)

20. Z. Ju, J. Sun, Y. Liu, Molecules 24(21), 3831 (2019)

21. J.L. Perez-Rodriguez, R. Perez-Maqueda, M.L. Franquelo, A. Duran, J. Therm. Anal. Calorim. 134, 15 (2018). https://doi.org/10.1007/s10973-017-6924-x

22. S.S. Bhattacharyan, S.B. Chaudhari, Int. J. Pure Appl. Sci. Techn. 21(1), 43 (2014)

23. J.V. Nardeli, C.S. Fugivara, E.R. Pereira Pinto, W.L. Polito, Y. Messaddeq, S.J. Lima Ribeiro, A.V. Benedetti, Polymers 11, 1890 (2019)

24. V. Muros, S.K.T.S. Wärmländer, D.A. Scott, J.M. Theile, J Am Inst Conserv 46(3), 229 (2007)

25. T.G. Weiszburg, K. Gherdan, K. Ratter, N. Zajzon, Z. Bendo, G. Radnoczi, A. Takacs, T. Vaczi, G. Varga, G. Szakmany, Anal Chem 89(20), 10753 (2017)

26. J.L. Perez-Rodriguez, A. Albardonedo, M.D. Robador, A. Duran, Microsc. Microanal. 24, 574 (2018)

27. A. Duran, R. Perez-Maqueda, J.L. Perez-Rodriguez, J. Cult. Herit. 36, 135 (2019)

28. M. Jaro, in Metal threads in historical textiles, in Molecular and Structural Archaeology: Cosmetic and Therapeutic Chemicals, (ed. By G. Tsoucaris, J. Lipkowski, Kluwer Academic Publishers, Dordrecht, The Netherlands, 2003), pp. 163-178

29. A. Baran, A. Fiedler, H. Schulz, M. Baranska, Anal. Methods 2, 1372 (2010)

30. H.G. Wiedemann, K.W. Brzezinka, K. Witke, I. Lamprecht, Thermochim. Acta 465, 56 (2007)

31. U. Knuutinen, A. Norman, Wax analysis in conservation objects by solubility studies, FTIR and DSC, in Proceedings of the 15th World Conference on Non-Destructive Testing, WCNDT-2000, Rome (Italy), 2000, pp. 15-21.

32. A. Burmester, Stud. in Conserv. 37, 73 (1992)

33. A. Karatzani, X-Ray Spectrom. 37, 410 (2008)

34. J. Contreras Vargas, Intervención, 1, 45 (2010)

35. T. Palomar, B. Ramírez Barat, E. García, E. Cano, J. Cult. Herit. 17, 20 (2016)

36. J. Rudoe, Oxidized silver in the nineteenth century: the documentary evidence, in Metal Plating and Patination: Cultural, Technical and Historical Developments. ed. by S. La Nieve, P. Craddock (Boston, Butterworth-Heinemann, Oxford, 1993), pp. 161-170

37. A. Timar-Balaszy, D. Eastop, Chemical Principles of Textile Conservation (ed. Butterworth-Heinemann, Oxford, 2005).

38. E.S.B. Ferreira, A. Quye, H. McNab, A.N. Hulme, J. Wouters, J.J. Boon, Dyes Hist. Archaeol. 16/17, $179(2001)$

39. E.S. Rodriguez, A.A. Rodriguez, M.A.G. Rodriguez, M. del Egido, C. Camara, e-Conservation 15, 32 (2010)

40. B. Doherty, C. Miliani, I.V. Berghe, A. Sgamellotti, B.G. Brunetti, J. Raman Spectrosc. 39, 638 (2008)

41. D. Cardon, Natural Dyes: Sources, Tradition, Technology and Science (ed. Archetype Publications, London, 2007) 